\title{
EFFECT OF SUPPLEMENTING LEAFLET ON KNOWLEDGE AND ATTITUDE TOWARD IMMUNIZATION AMONG MOTHERS IN LABUHAN BATU, NORTH SUMATERA
}

\author{
Eka Purnama Sari
}

Faculty of Public Health, Universitas Sumatera Utara

\begin{abstract}
Background: Immunization helps protect body from getting an infectious disease. It is important to give the right information to immunization among mothers. However, basic immunization coverage in Labuhan Batu, North Sumatera, was as low as 38.1\%. This study aimed to investigate the effect of supplementing leaflet on immunization use among mothers in Labuhan Batu, North Sumatera.

Subjects and Method: A quasi experiment was conducted at Teluk Santosa community health center, North Sumatera. A total of 75 pregnant mothers in trimester III was selected for this study. Pregnant mothers were divided into 2 groups: lecture and leaflet (intervention group) and lecture only (control group). The dependent variables were knowledge and attitude toward immunization. The independent variable was supplementing leaflet. The data were collected by questionnaire and analyzed by t test.

Results: The mean scores of knowledge and attitude were higher in the intervention group than in the control group, and they were statistically significant.

Conclusion: Lecture supplemented with leaflet is more effective than lecture alone in improving knowledge and attitude toward immunization among pregnant mothers.

Keywords: immunization, lecture, leaflet, pregnant mothers

Correspondence:

Eka Purnama Sari. Faculty of Public Health, Universitas Sumatera Utara, Medan, North Sumatera. Email: ekapurnamasari268@yahoo.com. Mobile: 081264858474.
\end{abstract}

The $5^{\text {th }}$ International Conference on Public Health

Best Western Premier Hotel, Solo, Indonesia, February 13-14, 2019 | 180 https://doi.org/10.26911/theicph.2019.02.25 